\title{
FINANSOWANIE SPORTU PRZEZ JEDNOSTKI SAMORZĄDU TERYTORIALNEGO W POLSCE - STUDIUM PRZYPADKU GMINY MIEJSKIEJ SKIERNIEWICE
}

Kacper Kowalczyk

Wydział Ekonomiczno-Socjologiczny, Uniwersytet Łódzki

\section{Streszczenie}

Artykuł zawiera informacje dotyczące pojęcia sportu i kultury fizycznej oraz ich finansowania przez jednostki samorządu terytorialnego. Sport jest współcześnie zjawiskiem wszechobecnym. Dla niektórych ludzi stanowi sposób spędzania wolnego czasu, relaksu, dbania o zdrowie, natomiast dla innych jest źródłem utrzymania. Zapewnienie odpowiednich warunków jego uprawiania stanowi ważny aspekt działalności władz centralnych oraz lokalnych. Niezbędne dla zapewnienia odpowiedniej infrastruktury sportowej jest dbanie o jej rozwój i zapewnienie odpowiednich uwarunkowań prawno-finansowych już na najniższych szczeblach struktury organów publicznych. Jednostki samorządowe stają przed problemem pozyskania środków na finansowanie sportu i ich odpowiedniego rozdysponowania. Celem artykułu jest przedstawienie wydatków budżetu Gminy Miejskiej Skierniewice na sport i kulturę fizyczną, a także ocena na jej przykładzie sposobu dystrybucji środków finansowych przez jednostki samorządu terytorialnego.

Słowa kluczowe: jednostka samorządu terytorialnego, finansowanie, sport, finanse publiczne.

JEL Class: R51, R23, R11, Z23. 


\section{WPROWADZENIE}

Współcześnie sport i kultura fizyczna stanowią ważny czynnik wpływający na społeczeństwa, zarówno te globalne jak i lokalne. Czynnik ten stanowi nieodłączny element ludzkiego życia, kształtuje postawy, zachowania i wydatnie przyczynia się do integracji grup ludności, a także budowania świadomości lokalnej. Istotnym jest więc, by wszelka działalność sportowa miała zagwarantowane szanse jak najszybszego i jak najefektywniejszego rozwoju. Gwarantem takiego stanu rzeczy jest kształtowanie korzystnej koniunktury na poziomie międzynarodowym, krajowym, ale też lokalnym. Znalezienie najlepszych strategii dla rozwoju sportu i kultury fizycznej wymaga dogłębnej, naukowej analizy socjologicznej, ale też ekonomicznej. Zarządzanie, nadzorowanie i wspieranie tej dziedziny wpisane jest w listę zadań jednostek samorządu terytorialnego już na poziomie gminnym. Środki budżetu gminy tworzą podstawy dla tworzenia warunków niezbędnych dla poprawnego rozwoju sportu. W związku z tym, kluczowym procesem jest kształtowanie odpowiedniej struktury wydatków, a także inteligentna dystrybucja środków finansowych na różne rodzaje sportowej działalności.

Celem artykułu jest przedstawienie wydatków budżetu Gminy Miejskiej Skierniewice na sport i kulturę fizyczną, a także ocena na jej przykładzie sposobu dystrybucji środków finansowych przez jednostki samorządu terytorialnego.

W artykule postawiono hipotezę mówiącą, że poziom dochodów własnych gminy determinuje zakres realizowanych zadań w obszarze sportu i kultury fizycznej. Weryfikacja hipotezy odbywa się poprzez porównanie, przy pomocy metod statystycznych, uśrednionej wielkości udziału wydatków na sport wśród ogółu wydatków budżetów wszystkich miast na prawach powiatu z tą samą wielkością w przypadku Gminy Miejskiej Skierniewice. Ocena słuszności hipotezy oparta jest następnie o analizę struktury i dynamiki wydatków badanej Gminy.

\section{SPORT JAKO ZADANIE WŁASNE SAMORZĄDU TERYTORIALNEGO}

Samorząd terytorialny jest częścią administracji publicznej, której podstawowym celem jest zaspokajanie potrzeb lokalnej społeczności, a także dbanie o jej rozwój. Cel ten realizowany jest poprzez wykonywanie szerokiego spektrum zadań [Podstawka 2013: 198].

Jak wynika $\mathrm{z}$ danych zawartych $\mathrm{w}$ tab. 1, według kryterium przynależności zadania samorządu terytorialnego dzielimy na własne, zlecone oraz powierzone. Konstytucja określa zadania własne jako takie, których celem jest zaspokajanie potrzeb wspólnoty samorządowej [Konstytucja Rzeczypospolitej Polskiej z dnia 2 kwietnia 1997 r., Dz.U. nr 78, poz. 483, z późn. zm., art. 167, ust. 1]. Zadania takie samorząd terytorialny realizuje we własnym zakresie i przy wykorzystaniu 
własnych środków finansowych. Jednostki szczebla regionalnego lub lokalnego ponoszą odpowiedzialność związaną z realizacją zadania własnego [Podstawka 2013: 198].

Tabela 1. Podział zadań samorządu terytorialnego

\begin{tabular}{|l|c|l|l|l|l|}
\hline Kryterium & \multicolumn{4}{|c|}{ Zadania jednostek samorządu terytorialnego } \\
\hline Przynależności & \multicolumn{2}{|c|}{ własne } & \multicolumn{2}{|c|}{ zlecone } & powierzone \\
\hline Powszechności & fakultatywne & obligatoryjne & fakultatywne & obligatoryjne & \\
\hline
\end{tabular}

Źródło: opracowanie wyłasne na podstawie Dylewski i in. [2006: 23].

Zadania zlecone to takie, które zostają przydzielone samorządom terytorialnym przez władze rządowe. Występują one, gdy państwo zauważa potrzebę podjęcia doraźnych działań na szczeblu regionalnym lub lokalnym, czy w przypadku inwestycji przeprowadzanych w ramach konkretnego programu polityki regionalnej. Koszty zadań zleconych są pokrywane ze środków pochodzących $\mathrm{z}$ dotacji celowych, co daje państwu prawo do weryfikowania efektywności realizowania danego zadania, a także zgodności z narzuconymi wytycznymi [Pietrzak $\mathrm{i}$ in. 2008: 31].

Samorządy terytorialne mogą również wykonywać zadania powierzone. Są to zadania, które dana jednostka wykonuje dobrowolnie, a ich przyjęcie następuje poprzez zawarcie porozumienia lub umowy. Mogą być one przyjmowane zarówno od organów władzy rządowej, jak również od innych jednostek samorządu terytorialnego [Dylewski i in. 2006: 20-21, 24].

Według ustawy o samorządzie gminnym „do zakresu działań gminy należą wszystkie sprawy publiczne o znaczeniu lokalnym, niezastrzeżone ustawami na rzecz innych podmiotów" [Ustawa z dnia 8 marca 1990 r..., Dz.U. 1998, nr 162, poz. 1126, art. 6, ust. 1]. Oznacza to, że oprócz kompetencji, które gmina uzyskała na mocy ustaw, powierzone zostają jej również zadania, które nie są przypisane innym podmiotom. Zadania własne gminy polegają na zaspokajaniu wspólnotowych potrzeb. Ustawa wskazuje, że zadania własne gminy dotyczą m.in. spraw infrastruktury technicznej, bezpieczeństwa i porządku publicznego, ładu przestrzennego i ekologicznego, infrastruktury społecznej [Ustawa z dnia 8 marca 1990 r..., Dz.U. 1998, nr 162, poz. 1126, art. 7].

Zadania związane $\mathrm{z}$ infrastrukturą społeczną to m.in. ochrona zdrowia, pomoc społeczna, działania edukacyjne i polityka prorodzinna. Zaliczyć można do nich również działalność kulturalną, w tym również przedsięwzięcia związane z kulturą fizyczną, sportem czy turystyką. Oznacza to, że zadanie dbania o infrastrukturę sportową i jej rozwój zostało prawnie przypisane jednostkom samorządu terytorialnego już na najniższym szczeblu. 
Pojęcie sportu zostało wyjaśnione $\mathrm{w}$ polskim prawie $\mathrm{w}$ Ustawie $\mathrm{z}$ dnia 25 czerwca 2010 r. o sporcie [Dz.U. 2010, nr 127, poz. 857 ze zm]. Przedstawione w niej wyjaśnienie stanowi, że „sportem są wszelkie formy aktywności fizycznej, które przez uczestnictwo doraźne lub zorganizowane wpływają na wypracowanie lub poprawienie kondycji fizycznej i psychicznej, rozwój stosunków społecznych lub osiągnięcie wyników sportowych na wszelkich poziomach" [Ustawa z dnia 25 czerwca 2010 r..., Dz.U. 2010, nr 127, poz. 857, ze zm., art. 2, ust. 1].

Obecnie wśród głównych form uprawiania sportu wskazuje się sport wyczynowy, a także sport powszechny. Występują dwa rodzaje sportu wyczynowego, a mianowicie sport zawodowy oraz amatorski. Z kolei na sport powszechny składają się turystyka kwalifikowana oraz sport rekreacyjny. Formy uprawiania sportu przedstawione zostały w tab. 2 .

Tabela 2. Formy partycypacji sportowej

\begin{tabular}{|c|c|c|c|c|c|}
\hline \multicolumn{2}{|c|}{$\begin{array}{c}\text { Sport wyczynowy } \\
\text { (kwalifikowany) }\end{array}$} & \multicolumn{2}{c|}{ Sport powszechny } & Sport szkolny & $\begin{array}{c}\text { Sport osób } \\
\text { niepelnosprawnych }\end{array}$ \\
\hline $\begin{array}{c}\text { Zawodowy } \\
\text { (profesjonalny) }\end{array}$ & amatorski & rekreacyjny & $\begin{array}{c}\text { turystyka } \\
\text { kwalifikowana }\end{array}$ & \\
\hline
\end{tabular}

Źródło: opracowanie własne na podstawie: Niedzielski i in. (red.) [2008: 9].

Podstawowym celem partycypacji w sporcie wyczynowym, a zarazem jego istotą jest zacięta rywalizacja między uczestnikami, a także zwycięstwo $w$ tejże rywalizacji. Może on być uprawiany przez amatorów lub przez zawodowców [Sznajder 2008: 16].

Celem uczestnictwa w sporcie amatorskim jest sama idea współzawodnictwa i ludzka potrzeba osiągnięcia satysfakcji z odniesionego sukcesu. Partycypanci sportu amatorskiego nie uprawiają go dla osiągnięcia korzyści materialnej, lecz z chęci samorealizacji i podkreślenia swojej wyższości nad rywalami [Sznajder 2008: 16].

Obecnie bardzo dużą popularnością cieszy się sport zawodowy, inaczej profesjonalny. Sport stał się biznesem, a ludzie i organizacje dostrzegają w nim możliwość osiągnięcia korzyści ekonomicznych. Stanowi on obecnie ważny element światowej gospodarki. Rozwój oraz wzrost znaczenia sportu zawodowego we współczesnym świecie wynika z procesu jego komercjalizacji oraz profesjonalizacji. Dla wielu osób kluczowa jest możliwość wykorzystania swoich nieprzeciętnych umiejętności do osiągnięcia korzyści finansowej [Sporek 2007: 60-61].

Sport powszechny, podobnie jak wskazane wcześniej formy uprawiania sportu, również jest oparty na rywalizacji i współzawodnictwie. Jednakże, celem 
partycypacji w tym przypadku jest chęć wykorzystania czasu wolnego w sposób aktywny, korzystny dla zdrowia, psychiki oraz sprawności fizycznej [Sznajder 2008: 16]. Podstawową formą sportu powszechnego jest rekreacja. Jest to „,forma działania dobrowolnie wybrana przez człowieka ze względu na osobiste zainteresowania i dla własnej satysfakcji, podejmowana poza obowiązkami zawodowymi i domowymi, w czasie wolnym od pracy, jest stałym i pochodnym elementem czasu wolnego, a ten z kolei naturalnym i koniecznym dopełnieniem pracy" [Toczek-Werner 2005: 10]. Rekreacja jest więc narzędziem służącym do relaksacji oraz zmniejszenia poziomu stresu związanego z codziennymi zajęciami, takimi jak praca zawodowa.

\section{PRAWNOFINANSOWE ASPEKTY WSPIERANIA SPORTU PRZEZ SAMORZAZD GMINNY}

Zgodnie z ustawą o sporcie z 2010 r. ,tworzenie warunków, w tym organizacyjnych, sprzyjających rozwojowi sportu stanowi zadanie własne jednostek samorządu terytorialnego" [Ustawa z dnia 25 czerwca 2010 r..., Dz.U. 2010, nr 127, poz. 857 , ze zm., art. 27, ust. 1]. Działalność gminy obejmuje m.in. wspieranie rozwoju kultury fizycznej oraz utrzymywanie terenów rekreacyjnych, a także obiektów sportowych [Ustawa z dnia 8 marca 1990 r..., Dz.U. 1998, nr 162, poz. 1126 , art. 7 , ust. 1 , pkt. 10].

W związku z powyższym, samorząd gminny, by skutecznie realizować założenia związane z prowadzaniem działalności sportowej musi posiadać szeroki zakres źródeł finansowania. Działalność sportowa stanowi zadanie własne samorządu gminnego, więc będzie ona mogła zostać pokryta z większości źródeł finansowania samorządów, które przedstawione zostały w tab. 3 .

Tabela 3. Struktura dochodów jednostek samorządu terytorialnego według ustawy o dochodach jednostek samorządu terytorialnego

\begin{tabular}{|c|c|c|}
\hline \multicolumn{2}{|c|}{ Dochody samorządu gminnego } \\
\hline Dochody własne & subwencje ogólne & $\begin{array}{r}\text { dotacje celowe } \\
\text { z budżetu państwa }\end{array}$ \\
\hline
\end{tabular}

Źródło: opracowanie własne na podstawie: Ustawa z dnia 13 listopada 2003 r... [Dz.U. 2003, nr 203, poz. 1966, art. 3 ust. 1].

W przypadku niektórych ze źródeł finansowania samorządu gminnego występują pewne ograniczenia, które odróżniają sposób finansowania sportu od sposobu finansowania innych dziedzin.

Zagadnienia finansowania sportu oraz kultury fizycznej poruszone zostały przez polskie władze $\mathrm{w}$ wielu aktach prawnych. Jednym $\mathrm{z}$ nich jest Ustawa 
z 2003 r. o działalności pożytku publicznego i wolontariacie [Dz.U. 2003, nr 96, poz. 873 , ze zm]. Określa ona zasady funkcjonowania oraz rodzaje organizacji pożytku publicznego. Zgodnie $\mathrm{z}$ nią ,działalnością pożytku publicznego jest działalność społecznie użyteczna, prowadzona przez organizacje pozarządowe w sferze zadań publicznych określonych w ustawie" [Ustawa z dnia 24 kwietnia 2003 r..., Dz.U. 2003, nr 96, poz. 873, ze zm., art. 3]. Z kolei organizacje pozarządowe to organizacje, które nie należą do sektora finansów publicznych, których celem nie jest generowanie zysku lub osoby prawne i jednostki organizacyjne, które nie mają osobowości prawnej, takie jak stowarzyszenia i fundacje [Ustawa z dnia 24 kwietnia 2003 r..., Dz.U. 2003, nr 96, poz. 873, ze zm., art. 3]. Działalność organizacji pozarządowych obejmuje m.in. wspieranie rozwoju, a także zwiększanie popularności kultury fizycznej. Samorządy terytorialne mogą zlecać wykonanie poszczególnych zadań, w tym tych z zakresu działalności sportowej, organizacjom pożytku publicznego, co wiąże się z koniecznością całkowitego pokrycia kosztów takiej działalności. Ponadto mogą wspierać realizowaną już działalność pożytku publicznego. W tym przypadku nie muszą pokrywać wszystkich kosztów, lecz jedynie wspomagają działalność określoną kwotą [Babczuk i Talik (red.) 2014: 35]. Zgodnie z ustawą „wspieranie oraz powierzanie zadań publicznych, może nastąpić na zasadach i w trybie przepisów o partnerstwie publiczno-prywatnym albo na podstawie umów międzynarodowych, jeżeli na realizację określonego zadania publicznego będą przekazywane niepodlegające zwrotowi środki ze źródeł zagranicznych" [Ustawa z dnia 24 kwietnia 2003 r..., Dz.U. 2003, nr 96, poz. 873, ze zm., art. 5, ust. 1].

Jednym z rodzajów organizacji pożytku publicznego mogą być kluby sportowe, które nie działają dla osiągnięcia zysku, a całość dochodu przeznaczają na wykonywanie zadań wynikających $\mathrm{z}$ ich statutu [Rzeszowski 2017: 48]. W związku z powyższym, jednostki samorządu terytorialnego mają możliwość wspomagania, przy użyciu środków z dotacji celowych, jedynie działalności obejmującej sport niezarobkowy, amatorski. W ten sposób odcina się od dodatkowych źródeł finansowania podmioty sektora prywatnego, takie jak kluby sportowe, które poza prowadzeniem działalności sportowej dążą też do wygenerowania zysku. Ponadto o uzyskanie dotacji starać się mogą tylko grupy sformalizowane, których funkcjonowanie jest określone w przepisach prawnych [Babczuk 2012: 138]. Dotacja może zostać przydzielona także specjalnemu rodzajowi klubu sportowego. Jest nim uczniowski klub sportowy. Możliwość wypłacenia takiemu podmiotowi dotacji wynika z przytoczonego wcześniej warunku, którym jest działalność nie dla osiągnięcia zysku [Prawo budżetowe państwa i samorzadu: 48]. Udzielenie dotacji danemu podmiotowi obliguje organ stanowiący do określenia sposobu, w jaki nadzorowane będzie wykorzystanie dotacji i stopień wykonania celu publicznego w zakresie kultury fizycznej. W związku z tym, znany musi być podmiot, który będzie przeprowadzał kontrolę, tryb do- 
kumentacji wszelkich czynności weryfikacyjnych, częstotliwość, miejsce oraz przewidywany zakres tej kontroli. Ponadto, przedstawione muszą zostać obowiązki oraz prawa podmiotu udzielającego dotacji, a także tego, który dotacje otrzyma [Sawicka 2012: 253].

Kolejnym ważnym aktem normatywnym regulującym finansowanie działalności sportowej przez gminę i jednostki wyższego szczebla jest Ustawa o sporcie z 2010 r. [Ustawa z dnia 25 czerwca 2010 r..., Dz.U. 2010, nr 127, poz. 857, ze zm.]. Określone zostały w niej m.in. cele na jakie kluby sportowe mogą otrzymać dotacje. Należą do nich [Ustawa z dnia 25 czerwca 2010 r..., Dz.U. 2010, nr 127, poz. 857 ze zm., art. 28, ust. 2]:

- wykonywanie programów szkolenia sportowego,

- nabycie sprzętu sportowego,

- finansowanie partycypacji w zawodach sportowych lub ich organizacji,

- opłacenie kosztów związanych z użytkowaniem obiektów sportowych,

- wypłacanie stypendiów sportowych i wynagrodzeń dla kadry szkoleniowej.

Ustawa o sporcie stanowi również, że dotacja może zostać wypłacona, tylko jeżeli realizacja wymienionych wyżej celów wpłynie na poprawę warunków uprawiania sportu lub zwiększy dostępność społeczności lokalnej do partycypacji w danym klubie. Ponadto określa ona aspekty, które muszą zostać uregulowane przy udzielaniu danemu podmiotowi wsparcia przez jednostkę samorządu terytorialnego. Są to [Ustawa z dnia 25 czerwca 2010 r..., Dz.U. 2010, nr 127, poz. 857 , ze zm., art. 28 , ust. 2]:

- rodzaj wsparcia (np. finansowe, czy organizacyjne),

- warunki udzielenia wsparcia,

- sposób finansowania,

- cel sportowy, jaki ma zostać zrealizowany poprzez udzielenie wsparcia.

W przypadku, gdy udzielenie dotacji celowej przez jednostkę samorządu terytorialnego jest $\mathrm{z}$ jakiegoś powodu niemożliwe, przekazanie środków finansowych danemu podmiotowi może zostać zrealizowane na podstawie umowy cywilnoprawnej [Babczuk 2012: 137].

Ustawa o sporcie daje jednostkom samorządu terytorialnego możliwość przyznawania okresowych stypendiów oraz nagród za osiągane rezultaty sportowe, niezależnie od tego, w jakim klubie zrzeszony jest beneficjent stypendium. Stypendia otrzymać mogą nie tylko zawodnicy lecz również członkowie kadry szkoleniowej [Ustawa z dnia 25 czerwca 2010 r..., Dz.U. 2010, nr 127, poz. 857, ze zm., art. 31]. Regulamin i sposób przyznawania stypendiów jest określany przez organ stanowiący jednostki samorządu terytorialnego. W trakcie tej procedury pod uwagę brane jest znaczenie, jakie dana dyscyplina sportowa ma dla samorządu, który posiada dużą swobodę w definiowaniu kluczowych kryteriów przyznawania stypendium. Jedynym ograniczeniem, jakie wprowadził w tym przypadku ustawodawca, jest wybór odbiorców stypendium i wysokości tego 
stypendium adekwatnie do osiąganych przez nich wyników i znaczenia tych wyników dla lokalnego społeczeństwa [Sawicka 2012: 253].

Gmina, oprócz udzielania wsparcia finansowego organizacjom, posiada prawo do wspomagania ich poprzez darowizny. Ustawa o gospodarce nieruchomościami stanowi, że ,nieruchomość może być przedmiotem darowizny na cele publiczne, a także przedmiotem darowizny dokonywanej między Skarbem Państwa a jednostką samorządu terytorialnego, a także między tymi jednostkami. W umowie darowizny określa się cel, na który nieruchomość jest darowana" [Bończak-Kucharczyk 2013: 124]. Oznacza to, że samorząd gminny może w formie darowizny przekazać klubowi sportowemu nieruchomość do realizacji celów publicznych.

Wspieranie działalności sportowej przez samorząd gminny może mieć charakter pośredni i wynikać z przepisów prawa podatkowego. W tym przypadku zawodnicy lub inne podmioty prowadzące działalność sportową mogą zostać zwolnione z płacenia podatku lub też zapłacić mniejszą jego kwotę. Wśród takich form wspierania sportu wyróżnia się [Leciak (red.) 2017: 39]:

- ulgi i zwolnienia podatkowe określone ustawowo lub w drodze uchwały JST,

- odroczenie terminu płatności zobowiązań podatkowych,

- ratalny system spłaty podatku,

- rezygnacja ze ściągnięcia podatku od danego podmiotu, wynikająca z odpowiedniego rozporządzenia ministra finansów.

Zadania z zakresu sportu i kultury fizycznej mogą być realizowane przez organizacje pozarządowe, które otrzymują zlecenie na realizacje danego zadania w ramach ogłoszonego przez organ publiczny konkursu ofert. Organ przeprowadzający konkurs musi przedstawić informacje o [Sawicka 2012: 260]:

- rodzaju zadania,

- terminach składania i wyboru ofert,

- sposobie wyboru ofert i szczegółowych kryteria ich oceny,

- rodzaju zadania,

- kwocie publicznych środków wydatkowanych na zlecenie danego zadania,

- zrealizowanych w roku bieżącym i ubiegłym zadaniach tego samego typu i kosztach z tym związanych.

Ustawa o finansach publicznych stanowi, że jednostki samorządu terytorialnego mogą realizować swoje zadania poprzez samorządowe zakłady budżetowe, które wykonują swoje zadania odpłatnie i z pozyskanych w ten sposób przychodów, pokrywają koszty swojej działalności. Działalność ta może obejmować także zadania własne jednostki samorządu terytorialnego w zakresie ,kultury fizycznej i sportu, w tym utrzymania terenów rekreacyjnych i urządzeń sportowych" [Ustawa z dnia 27 sierpnia 2009 r..., Dz.U. 2009, nr 157, poz. 1240, ze zm., art. 14]. 
Ustawodawca przewidział możliwość wykonywania zadań publicznych, w tym również tych związanych ze sportem i kulturą fizyczną dzięki inicjatywie lokalnej społeczności, co zostało określone w ustawie z 2010 r. o zmianie ustawy o działalności pożytku publicznego i o wolontariacie oraz niektórych innych ustaw [Sawicka 2012: 266]. Mieszkańcy otrzymują możliwość przedstawienia wniosku o realizację danego zadania publicznego w swoim miejscu zamieszkania. Jednostka samorządu terytorialnego może wspomagać takie przedsięwzięcie rzeczowo, finansowo oraz udzielać wsparcia organizacyjnego. Wniosek, w którym zawarty zostaje pomysł na realizację zadania publicznego oraz deklarację współudziału w przedsięwzięciu, przekazują bezpośrednio lub przy pomocy organizacji pozarządowych jednostkom samorządu terytorialnego. Współudział ten, może odbywać się na zasadzie świadczeń zarówno rzeczowych, jak i pieniężnych oraz pracy społecznej [Sawicka 2012: 266-267].

Stale rosnąca popularność sportu sprawiła, że niezbędne stało się szczegółowe uregulowanie prawne samego funkcjonowania działalności sportowej. Polski ustawodawca, uchwalając szereg ustaw przewidział dla gmin, powiatów oraz województw szeroki zakres możliwości związanych z jej wspieraniem.

\section{FINANSOWANIE DZIALALNOŚCI SPORTOWEJ PRZEZ SAMORZĄD GMINNY - STUDIUM PRZYPADKU}

Dane badawcze przedstawione w artykule dotyczą miasta Skierniewice, funkcjonującego na prawach powiatu. Jego powierzchnia wynosi około $34,6 \mathrm{~km}^{2}$, co plasuje je na siódmej pozycji wśród największych miast województwa łódzkiego. Gmina jest położona między Łodzią a Warszawą, na terenie województwa łódzkiego. W roku 2016 liczba ludności zamieszkującej Skierniewice wynosiła 48327 osób, z czego 52,16\% stanowiły kobiety, a 47.84\% mężczyźni [Skierniewice - podstawowe informacje, dostęp: 25.02.2018].

$\mathrm{W}$ gminie miejskiej Skierniewice organem odpowiedzialnym za uchwalanie budżetu jest Rada Miasta Skierniewice. Budżet uchwalany jest raz w roku, natomiast sprawozdanie z jego wykonania jest publikowane raz na kwartał. Plan budżetu zawiera informacje dotyczące prognozowanych dochodów i wydatków w podziale na bieżące i majątkowe. Ponadto, określa on przewidywane saldo budżetu, a w przypadku wystąpienia deficytu wskazuje źródła jego finansowania [Sprawozdania z wykonania budżetu Miasta Skierniewice..., dostęp: 15.03.2018]. W tabeli 4 oraz na wykresie 1 przedstawione zostało wykonanie wydatków gminy miejskiej Skierniewice w latach 2010-2016.

Jak wynika $\mathrm{z}$ danych przedstawionych $\mathrm{w}$ tab. 4 i na wykresie 1, w ogólnej liczbie wydatków gminy miejskiej Skierniewice w latach 2010-2016 największy udział mają wydatki bieżące (od ok. $75 \%$ do ok. $88 \%$ ), a wśród nich większość 
stanowią wydatki jednostek budżetowych. Ponadto od 7\% do 8\% środków przeznaczane jest na udzielanie dotacji na zadania bieżące. Około 6\% budżetu rocznie jest przekazywane w formie świadczeń na rzecz osób fizycznych, z wyjątkiem roku 2016, w którym wartość świadczeń pochłonęła ok. 15\% budżetu (było to związane z inicjacją programu 500+). Nieznaczna część środków jest przeznaczana na dotacje z udziałem środków z Unii Europejskiej oraz na obsługę długu. Pozostałą część stanowią wydatki majątkowe, takie jak inwestycje oraz zakupy inwestycyjne.

Tabela 4. Wykonanie wydatków gminy miejskiej Skierniewice w latach 2010-2016 (w tys. zł)

\begin{tabular}{|l|c|c|c|c|c|c|c|}
\hline Wyszczególnione & 2010 & 2011 & 2012 & 2013 & 2014 & 2015 & 2016 \\
\hline Wydatki bieżące & $\mathbf{1 4 0 ~ 0 6 6 , 5 9}$ & $\mathbf{1 5 6} \mathbf{5 4 6 , 0 7}$ & $\mathbf{1 5 6} \mathbf{6 7 6 , 6 6}$ & $\mathbf{1 6 4} \mathbf{8 2 2 , 3 8}$ & $\mathbf{1 7 3} \mathbf{6 2 8 , 1 7}$ & $\mathbf{1 7 6} \mathbf{8 7 1 , 2 5}$ & $\mathbf{2 0 7} \mathbf{0 9 7 , 7 1}$ \\
\hline $\begin{array}{l}\text { Wydatki jednostek } \\
\text { budżetowych }\end{array}$ & 111282,56 & 126582,52 & 124269,5 & 132613,38 & 139980,17 & 142873,17 & 151246,23 \\
\hline $\begin{array}{l}\text { Dotacje na zadanie } \\
\text { bieżące }\end{array}$ & 13139,09 & 14917,26 & 15813,95 & 15676,43 & 16211,45 & 17253,38 & 18236,37 \\
\hline $\begin{array}{l}\text { Świadczenia na rzecz } \\
\text { osób fizycznych }\end{array}$ & 11590,96 & 11879,74 & 12099,18 & 13001,1 & 13262,35 & 13790,8 & 35163,01 \\
\hline $\begin{array}{l}\text { Wydatki z udziałem } \\
\text { śodków z UE }\end{array}$ & 3493,11 & 1454,6 & 1470,89 & 1272,69 & 2303,12 & 1183,18 & 488,47 \\
\hline Obsługa długu & 560,87 & 1711,95 & 3023,14 & 2258,78 & 1871,08 & 1770,74 & 1963,63 \\
\hline Wydatki majątkowe & 45930,3 & 36886,85 & 27161,39 & 29956,04 & 38457,92 & 44943,07 & 28832,68 \\
\hline Inwestycje & 42574,6 & 32634,71 & 25236,94 & 28934,23 & 35984,37 & 38993,75 & 25315,36 \\
\hline $\begin{array}{l}\text { Zakupy inwestycyjne } \\
\text { Wniesienie wkładów } \\
\text { do spółek prawa } \\
\text { handlowego }\end{array}$ & 100 & 1300 & 50 & 50 & 50 & 3888 & 700 \\
\hline Razem & 185996,89 & 193432,93 & 183838,06 & 194778,42 & 212086,09 & 221814,32 & 235930,39 \\
\hline
\end{tabular}

Źródło: opracowanie własne na podstawie Sprawozdań z wykonania budżetu Miasta Skierniewice w latach 2010-2016, www.bip.um.skierniewice.pl [dostęp: 15.03.2018].

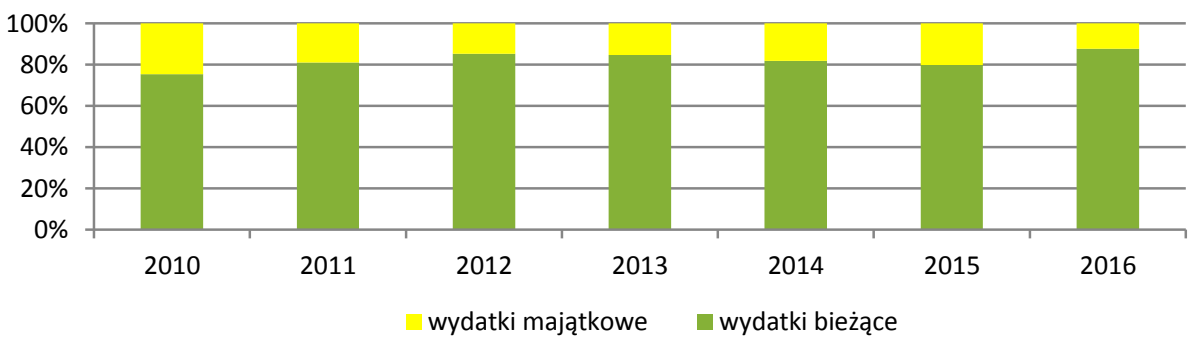

Wykres 1. Struktura wydatków budżetu gminy miejskiej Skierniewice w latach 2010-2016

Źródło: opracowanie własne na podstawie tab. 4. 
W tabeli 5 oraz na wykresie 2 przedstawione zostało wykonanie dochodów budżetu gminy miejskiej Skierniewice w latach 2010-2016.

Funkcjonowanie gminy miejskiej Skierniewice jest oparte na wielu stabilnych źródłach dochodów. Dochody własne w latach 2010-2016 wykazują nieprzerwaną tendencję wzrostową. Jest ona spowodowana stabilnym wzrostem składowych, takich jak podatki lokalne, udziały w podatkach dochodowych, subwencje ogólne z budżetu państwa. Dużą dynamiką cechują się dochody z opłat lokalnych (do około 57 p.p. rocznie) oraz z innych wpływów (do około 30 p.p. rocznie).

Ogólna liczba dochodów charakteryzuje się tendencją wzrostową, która w rezultacie doprowadziła do powiększenia się ich wartości na przestrzeni lat 2010-2016 o około 70 milionów złotych.

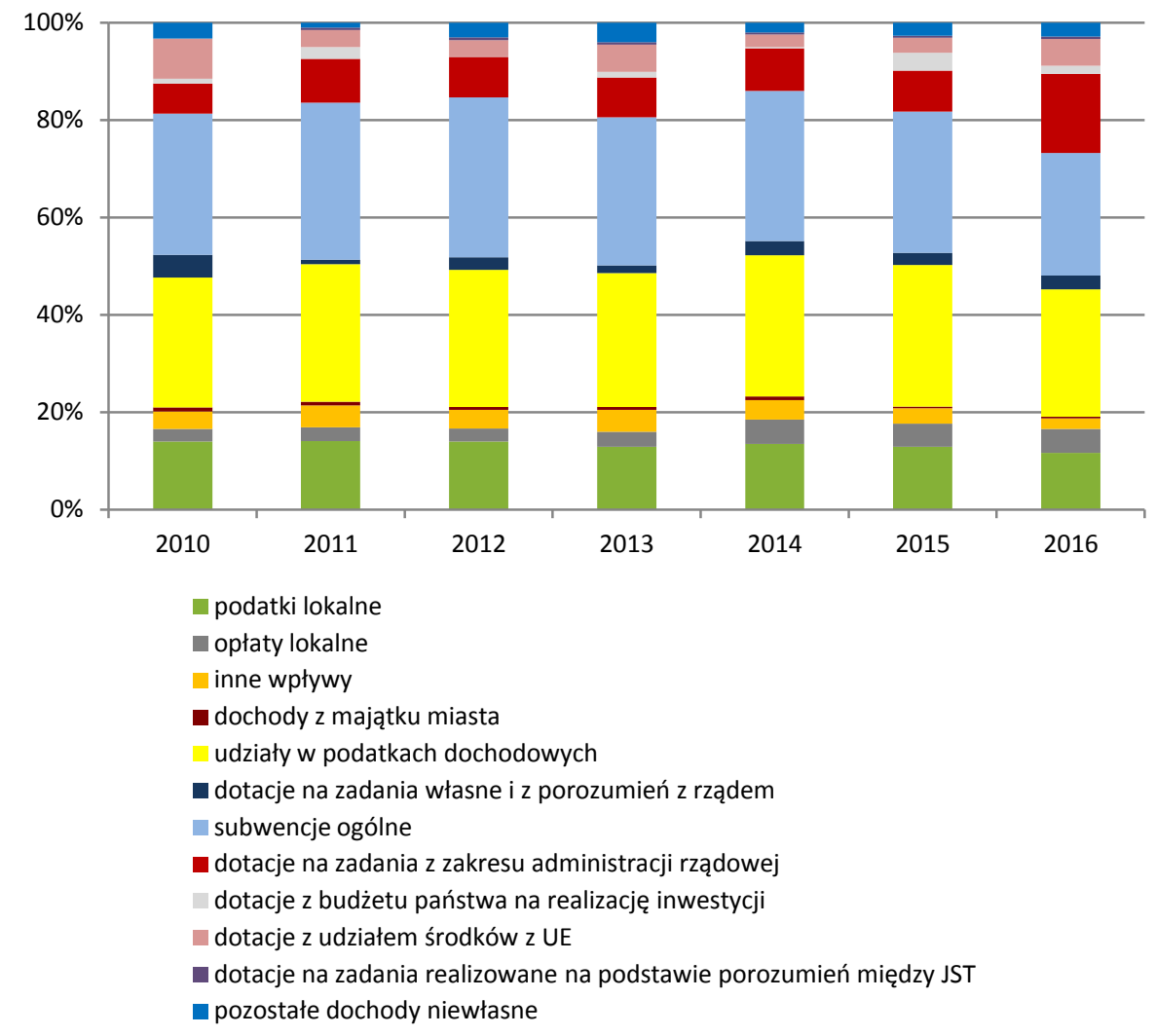

Wykres 2. Struktura dochodów budżetu gminy miejskiej Skierniewice w latach 2010-2016

Źródło: opracowanie własne na podstawie tabeli 5. 
Tabela 5. Wykonanie dochodów budżetu gminy miejskiej Skierniewice w latach 2010-2016 (w tys. zł)

\begin{tabular}{|c|c|c|c|c|c|c|c|}
\hline Wyszczególnione & 2010 & 2011 & 2012 & 2013 & 2014 & 2015 & 2016 \\
\hline Dochody wlasne & 141484,71 & 144476,43 & 151421,05 & 157881,82 & 167652,45 & 168640,01 & 178907,39 \\
\hline Podatki lokalne & 24284,76 & 24265,55 & 25007,08 & 25190,49 & 26321,33 & 26654,89 & 28497,43 \\
\hline Od nieruchomości & 19615 & 20394,58 & 21202,22 & 21711,33 & 22518,85 & 23094,99 & 24655,46 \\
\hline $\begin{array}{l}\text { Od czynności cywilno- } \\
\text {-prawnych }\end{array}$ & 2817,82 & 2104,99 & 1843,72 & 1501,94 & 2059,21 & 1827,97 & 1968,9 \\
\hline Leśny & 1,15 & 0,91 & 1,28 & 1,64 & 1,63 & 1,83 & 2,32 \\
\hline Karta podatkowa & 195,51 & 178,66 & 187,12 & 152,32 & 146,94 & 126,91 & 127,07 \\
\hline $\begin{array}{l}\text { Od spadków i daro- } \\
\text { wizn }\end{array}$ & 461,41 & 430,09 & 461,18 & 452,06 & 237,56 & 238,87 & 422,39 \\
\hline $\begin{array}{l}\text { Od środków transpor- } \\
\text { towych }\end{array}$ & 1082,42 & 1038,72 & 1084,01 & 1139,27 & 1135,39 & 1172,83 & 1151,31 \\
\hline Rolny & 111,45 & 117,6 & 227,55 & 231,93 & 221,74 & 191,5 & 169,99 \\
\hline Oplaty lokalne & 4623,13 & 4985,77 & 4836,73 & 6190,9 & 9745,36 & 9724,32 & 11967,08 \\
\hline Skarbowa & 606,64 & 554,93 & 551,14 & 507,66 & 498,28 & 420,65 & 447,21 \\
\hline Targowa & 730,07 & 833,49 & 823,58 & 784,41 & 778,84 & 791,55 & 765,65 \\
\hline Za koncesje i licencje & 935,11 & 931,86 & 1011,56 & 991,14 & 975,77 & 979,27 & 1009,62 \\
\hline Komunikacyjna & 982,28 & 964,97 & 897,39 & 920,42 & 947,27 & 979,49 & 875,42 \\
\hline Pozostałe opłaty & 1369,04 & 1700,52 & 1553,05 & 2987,28 & 6545,2 & 6553,36 & 8869,17 \\
\hline Inne wpływy & 6174,52 & 7759,82 & 6831,14 & 8783,76 & $7 \mathbf{7 0 5 , 3 8}$ & 6544,08 & 5329,96 \\
\hline Grzywny i mandaty & 590,08 & 1358,39 & 366,14 & 1705,85 & 671,58 & 137,57 & 360,26 \\
\hline Usługi & 2637,28 & 3627,24 & 3791,57 & 3599,01 & 3320,14 & 3323,19 & 1700,82 \\
\hline Z odsetek & 296,88 & 361,1 & 684,71 & 453,16 & 317,25 & 273,2 & 262,1 \\
\hline Pozostałe wpływy & 2650,28 & 2413,09 & 1988,73 & 3025,74 & 3396,41 & 2810,12 & 3006,77 \\
\hline $\begin{array}{l}\text { Dochody z majątku } \\
\text { miasta }\end{array}$ & 1384,88 & 1258,62 & 966,66 & 1039,03 & 1451,08 & 678,4 & 666,13 \\
\hline $\begin{array}{l}\text { Udziały w podatkach } \\
\text { dochodowych }\end{array}$ & 46474,39 & 48772,88 & 50437,22 & 53879,43 & 56537,73 & 60018,53 & 64006,06 \\
\hline $\begin{array}{l}\text { Dotacje na zadania } \\
\text { wlasne }\end{array}$ & 8089,87 & 1623,91 & 4597,02 & $3 \mathbf{1 5 5 , 8 7}$ & 5706,47 & 5156,52 & 6947,51 \\
\hline Subwencje ogólne & 50453,16 & 55809,87 & 58745,19 & 59642,34 & 60185,1 & 59863,26 & 61493,22 \\
\hline $\begin{array}{l}\text { Dotacje na zadania } \\
\text { z zakresu admini- } \\
\text { stracji rządowej }\end{array}$ & 10757,26 & 15503,76 & 14883,1 & 15905,6 & 16911,17 & 17299,08 & 39533,5 \\
\hline $\begin{array}{l}\text { Dotacje } \mathrm{z} \text { budżetu } \\
\text { państwa na realizację } \\
\text { inwestycji }\end{array}$ & 1761,82 & 4140,87 & 103,52 & 2265,49 & 550,13 & 7558,14 & 4126,74 \\
\hline $\begin{array}{l}\text { Dotacje z udziałem } \\
\text { środków z UE }\end{array}$ & 14393,61 & 6086,81 & 6010,08 & 11036,78 & 5022,13 & 6432,07 & 13379,58 \\
\hline $\begin{array}{l}\text { Dotacje na zadania } \\
\text { realizowane na } \\
\text { podstawie porozu- } \\
\text { mień między JST }\end{array}$ & $\mathbf{0}$ & 819,54 & 911,35 & 908,7 & 899,98 & 904,92 & 1306,45 \\
\hline $\begin{array}{l}\text { Pozostałe dochody } \\
\text { nie wlasne }\end{array}$ & 5683,51 & 1799,03 & 5475,39 & 7904,14 & 3875,94 & 5510,1 & 6940,04 \\
\hline Razem & 174080,91 & 172826,43 & 178804,5 & 195902,53 & 194911,8 & 206344,33 & 244193,69 \\
\hline
\end{tabular}

Źródło: opracowanie własne na podstawie Sprawozdań z wykonania budżetu Miasta Skierniewice... [dostęp: 15.03.2018]. 
W tabeli 6 przedstawiony został poziom salda budżetu i finansowanie deficytu gminy miejskiej Skierniewice w latach 2010-2016.

Tabela 6. Saldo budżetu oraz finansowanie deficytu gminy miejskiej Skierniewice w latach 2010-2016 (w tys. zł)

\begin{tabular}{|c|c|c|c|c|c|c|c|}
\hline Wyszczególnione & 2010 & 2011 & 2012 & 2013 & 2014 & 2015 & 2016 \\
\hline Dochody & 174080,91 & 172826,43 & 178799,5 & 195902,53 & 194911,8 & 206344,33 & 244193,69 \\
\hline Wydatki & 185996,89 & 193432,93 & 183838,06 & 194778,42 & 212086,09 & 221814,32 & 235930,39 \\
\hline Saldo budżetu & $-11915,98$ & $-20606,5$ & $-5038,56$ & 1124,11 & $-17174,29$ & $-15469,99$ & 8263,31 \\
\hline $\begin{array}{l}\text { Finansowanie } \\
\text { deficytu }\end{array}$ & 21531,35 & 28355,18 & 11690,12 & 3612,3 & 20826,07 & 18272,89 & 3907,09 \\
\hline Przychody & 28149,03 & 37488,36 & 21638,13 & 23942,8 & 27892,08 & 26034,7 & 12810,94 \\
\hline $\begin{array}{l}\text { W tym: kredyty } \\
\text { i pożyczki }\end{array}$ & 28846,58 & 27872,99 & 13846,98 & 0 & 23155,67 & 22355,2 & 10000 \\
\hline Obligacje & 0 & 0 & 0 & 17000 & 0 & 0 & 0 \\
\hline Wolne środki & 0 & 0 & 0 & 0 & 4736,41 & 3679,5 & 2810,94 \\
\hline Inne źródła & $-697,55$ & 9615,37 & 7791,15 & 6942,8 & 0 & 0 & 0 \\
\hline Rozchody & 6617,68 & 9133,18 & 9948,01 & 20330,5 & 7066 & $7 \mathbf{7 6 1 , 8 2}$ & 8903,84 \\
\hline $\begin{array}{l}\text { W tym: spłaty } \\
\text { Kredytów i poży- } \\
\text { czek }\end{array}$ & 6617,68 & 9133,18 & 9948,01 & 20330,5 & 7066 & 7761,82 & 8903,84 \\
\hline
\end{tabular}

Źródło: opracowanie własne na podstawie Informacji z wykonania budżetu Miasta Skierniewice $\mathrm{z}$ lat 2010-2016 [dostęp: 14.03.2018].

Poziom salda budżetu gminy miejskiej Skierniewice w latach 2010-2016 przyjmuje postać sinusoidy. Ponadto na przestrzeni omawianych lat tylko dwukrotnie kwota dochodów budżetu przewyższała kwotę wydatków (w 2013 i w 2016 roku). Najwyższy deficyt środków Skierniewice odnotowały w roku 2011, gdy wyniósł on ponad $20 \mathrm{mln}$ zł. Z kolei największa nadwyżka finansowa pojawiła się w roku 2016 i wyniosła ponad $8 \mathrm{mln}$ zł. W latach 2010, 2011 i 2012 powstały deficyt budżetowy został sfinansowany poprzez zaciągnięte kredyty i pożyczki oraz środki pochodzące z innych źródeł. Ponadto część zaciągniętych kredytów została przeznaczona na spłatę zobowiązań z lat ubiegłych. W roku 2013 wystąpiła nadwyżka, a Miasto wyemitowało obligacje o wartości $17 \mathrm{mln}$ zł. Środki pochodzące $\mathrm{z}$ emisji oraz z innych źródeł zostały przeznaczone na spłatę kredytów i pożyczek z lat wcześniejszych. W roku 2015 Miasto zaciągnęło kredyty i pożyczki w kwocie przekraczającej $22 \mathrm{mln}$ zł i posiadało ponad 3,5 $\mathrm{mln}$ zł wolnych środków finansowych. Około 7,7 $\mathrm{mln}$ zł zostało przeznaczone na spłatę 
zobowiązań z poprzednich lat. W roku 2016 kwota dochodów budżetowych przewyższyła kwotę wydatków. Ponadto Miasto posiadało ok. 2,8 mln zł wolnych środków finansowych. Pozyskane środki przeznaczono na spłatę 8,9 mln zł zobowiązań z lat ubiegłych.

W tabeli 7 i na wykresie 3 przedstawione zostało wykonanie wydatków na sport w gminie miejskiej Skierniewice, ich struktura oraz dynamika w latach 2010-2016.

Tabela 7. Wykonanie oraz struktura wydatków budżetu na sport w gminie miejskiej Skierniewice w latach 2010-2016 (w tys. zł)

\begin{tabular}{|c|c|c|c|c|c|c|c|}
\hline Wyszczególnione & 2010 & 2011 & 2012 & 2013 & 2014 & 2015 & 2016 \\
\hline Obiekty sportowe & 5644,77 & 5357,2 & 3561,13 & 3804,36 & 5047,34 & 6756,65 & 10412,18 \\
\hline $\begin{array}{l}\text { Zadania w zakresie } \\
\text { kultury fizycznej } \\
\text { i sportu }\end{array}$ & 1331,06 & 1389,44 & 1387,29 & 1397,56 & 1464,7 & 1513,36 & 1471,75 \\
\hline $\begin{array}{l}\text { Pozostała działal- } \\
\text { ność }\end{array}$ & 436,11 & 0 & 0 & 93,25 & 0 & 0 & 228,04 \\
\hline Razem & 7411,95 & 6746,64 & 4948,42 & 5295,17 & 6512,04 & 8270,02 & 12111,97 \\
\hline $\begin{array}{l}\text { Udział w łącznej } \\
\text { liczbie wydatków na } \\
\text { sport: }\end{array}$ & & & & & & & \\
\hline $\begin{array}{l}\text { Obiektów sporto- } \\
\text { wych }\end{array}$ & $76,16 \%$ & $79,41 \%$ & $71,96 \%$ & $71,85 \%$ & $77,51 \%$ & $81,70 \%$ & $85,97 \%$ \\
\hline $\begin{array}{l}\text { Zadań z zakresu } \\
\text { kultury fizycznej } \\
\text { i sportu }\end{array}$ & $17,96 \%$ & $20,59 \%$ & $28,04 \%$ & $26,39 \%$ & $22,49 \%$ & $18,30 \%$ & $12,15 \%$ \\
\hline $\begin{array}{l}\text { Pozostałej działalno- } \\
\text { ści }\end{array}$ & $5,88 \%$ & $0,00 \%$ & $0,00 \%$ & $1,76 \%$ & $0,00 \%$ & $0,00 \%$ & $1,88 \%$ \\
\hline \multicolumn{8}{|l|}{$\begin{array}{l}\text { Dynamika wydat- } \\
\text { ków na: }\end{array}$} \\
\hline Obiekty sportowe & - & $-5,09 \%$ & $-33,53 \%$ & $6,83 \%$ & $32,67 \%$ & $33,87 \%$ & $54,10 \%$ \\
\hline $\begin{array}{l}\text { Zadania z zakresu } \\
\text { kultury fizycznej } \\
\text { i sportu }\end{array}$ & - & $4,39 \%$ & $-0,15 \%$ & $0,74 \%$ & $4,80 \%$ & $3,32 \%$ & $-2,75 \%$ \\
\hline $\begin{array}{l}\text { Pozostałą działal- } \\
\text { ność }\end{array}$ & - & $-100,00 \%$ & $\#$ & $\#$ & $-100 \%$ & \# & \# \\
\hline $\begin{array}{l}\text { Łącznej sumy wy- } \\
\text { datków }\end{array}$ & - & $-8,98 \%$ & $-26,65 \%$ & $7,01 \%$ & $22,98 \%$ & $27,00 \%$ & $46,46 \%$ \\
\hline
\end{tabular}

Źródło: opracowanie własne na podstawie Sprawozdań z wykonania budżetu Miasta Skierniewic... [dostęp: 17.03.2018]. 


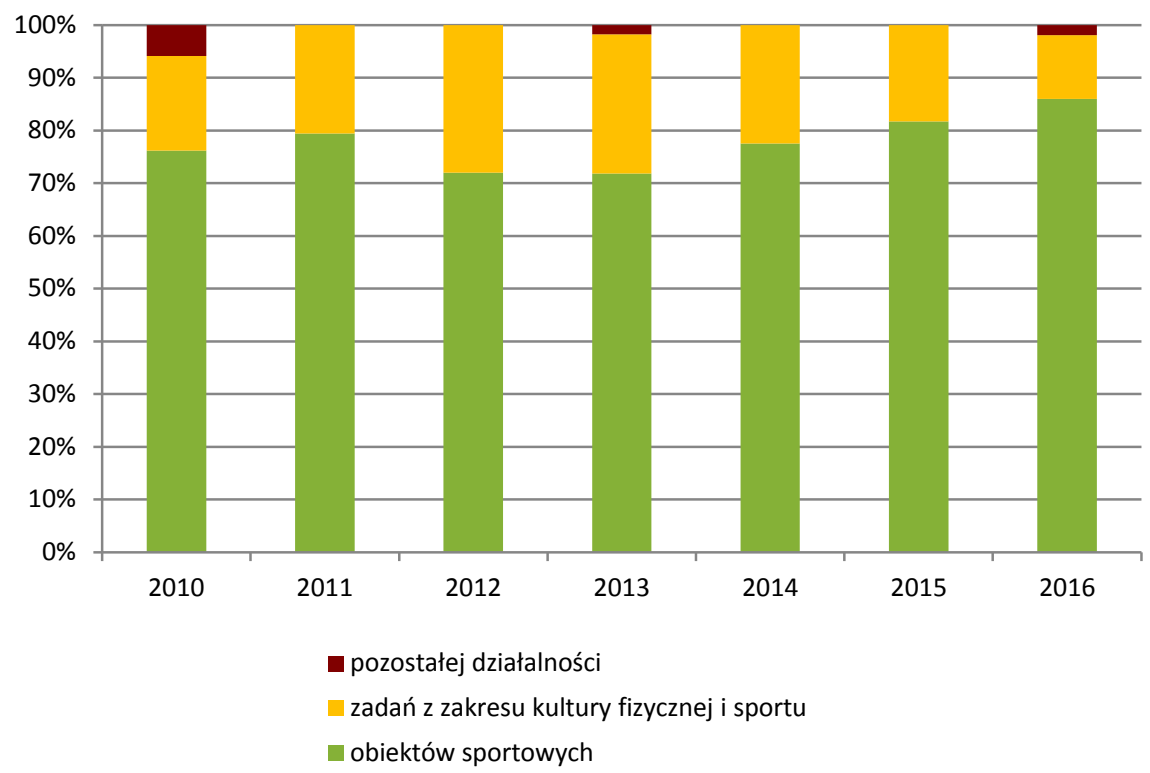

Wykres 3. Struktura wydatków budżetu na sport w minie miejskiej Skierniewice w latach 2010-2016 (w tys. zł)

Źródło: opracowanie własne na podstawie tabeli 7.

Suma i struktura wydatków na sport w gminie miejskiej Skierniewice na przestrzeni badanych lat charakteryzuje się dużą dynamiką. Od 2010 do 2012 roku wykazywała ona tendencją zniżkową. Po tym okresie, do roku 2016 wydatki na sport były coraz wyższe. Od roku 2012 do roku 2016 ich wzrost osiągnął około 145 p.p. Wysoka dynamika łącznej sumy środków wydatkowanych na działalność sportową wynikała ze znaczących zmian zachodzących w poszczególnych latach w kategorii wydatków na obiekty sportowe. Od 2012 r. gmina miejska Skierniewice sukcesywnie zwiększała ilość środków przeznaczanych na ich budowę, utrzymanie oraz modernizację. Pomiędzy 2012 a 2016 rokiem kwota ta zwiększyła się o około $6,8 \mathrm{mln}$ zł przy równoczesnym wzroście poziomu dochodów własnych. Wydatki związane $\mathrm{z}$ realizacją zadań $\mathrm{z}$ zakresu kultury fizycznej i sportu charakteryzowały się dużą stabilnością. Ich największa zanotowana zmiana wyniosła 4,8 p.p.

W tabeli 8 przedstawiono porównanie udziału wydatków na sport w Gminie Miejskiej Skierniewice ze średnim udziałem wydatków na sport miast na prawach powiatu. 
Tabela 8. Zestawienie średniego udziału wydatków na sport w ogólnej liczbie wydatków budżetów miast na prawach powiatu i w Gminie Miejskiej Skierniewice (w tys. zł)

\begin{tabular}{|l|c|c|c|c|c|c|c|}
\hline Wyszczególnione & 2010 & 2011 & 2012 & 2013 & 2014 & 2015 & 2016 \\
\hline Wydatki na sport & 7411,95 & 6746,64 & 4948,42 & 5295,17 & 6512,04 & 8270,02 & 12111,97 \\
\hline $\begin{array}{l}\text { Wydatki budżetu } \\
\text { ogółem) }\end{array}$ & 185996,89 & 193432,93 & 183838,06 & 194778,42 & 212086,09 & 221814,32 & 235930,39 \\
\hline $\begin{array}{l}\text { Udział wydatków na } \\
\text { sport w sumie wydat- } \\
\text { ków budżetu miasta } \\
\text { Skierniewice }\end{array}$ & $3,98 \%$ & $3,49 \%$ & $2,69 \%$ & $2,72 \%$ & $3,07 \%$ & $3,73 \%$ & $5,13 \%$ \\
\hline $\begin{array}{l}\text { Sredni udział wydat- } \\
\text { ków na sport w sumie } \\
\text { wydatków budżetów } \\
\text { miast na prawach } \\
\text { powiatu (wg. GUS) }\end{array}$ & $4,90 \%$ & $3,50 \%$ & $2,80 \%$ & $2,57 \%$ & $3,03 \%$ & $2,87 \%$ & $2,84 \%$ \\
\hline $\begin{array}{l}\text { Różnica pomiędzy } \\
\text { udziałem wydatków } \\
\text { na sport w Skiernie- } \\
\text { wicach i średnim } \\
\text { udziałem ogólnokra- } \\
\text { jowym }\end{array}$ & $0,92 \%$ & $0,01 \%$ & $0,11 \%$ & $0,15 \%$ & $0,04 \%$ & $0,86 \%$ & $2,29 \%$ \\
\hline $\begin{array}{l}\text { Współczynnik korela- } \\
\text { cji danych Miasta } \\
\text { Skierniewice i ogól- } \\
\text { nokrajowych }\end{array}$ & & & & & & & \\
\hline
\end{tabular}

Źródło: opracowanie własne na podstawie Sprawozdań z wykonania budżetu Miasta Skierniewice... [data dostępu 17.03.2018]; Główny Urząd Statystyczny, Gospodarka finansowa jednostek samorządu terytorialnego... [dostęp: 17.06.2019].

$\mathrm{Z}$ danych przedstawionych w tabeli 8 i na wykresie 4 wynika, że w Gminie Miejskiej Skierniewice średni udział wydatków na sport w sumie wydatków budżetu wynosił 3,54\%. Średnia policzona dla wszystkich miast na prawach powiatu wyniosła $3,22 \%$. Różnica pomiędzy danymi ogólnokrajowymi a tymi dotyczącymi Skierniewic mieściła się w przedziale od 0,01 p.p., a 2,29 p.p., a współczynnik korelacji kształtował się na poziomie 0,25 . Udział wydatków na sport w sumie wydatków budżetu kształtował się więc na zbliżonym poziomie w przypadku Gminy Miejskiej Skierniewice i innych miast na prawach powiatu, a największa różnica pomiędzy tymi udziałami była skutkiem znacznego zwiększenia wydatków na sport w Skierniewicach w roku 2016 (wzrost o 46\%). Zgodnie z klasyfikacją opracowaną przez J. Guilforda, współczynnik korelacji na poziomie 0,25 oznacza, że pomiędzy przedstawionymi udziałami występuje korelacja, jednakże jest ona relatywnie słaba [Witkowski (red.) 218: 23]. Oznacza to, że istnieje powiązanie pomiędzy wysokością wydatków na sport w poszczególnych miastach na prawach powiatu, ale wysokość ta zależy też od wielu różnych czynników, przez co powiązanie to nie jest silne. Warty podkreślenia jest fakt, że udział wydatków na sport w ogóle wydatków budżetu w Skierniewi- 
cach nie odbiega znacząco od uśrednionego udziału wydatków na sport w budżetach wszystkich miast działających na prawach powiatu, dlatego tendencje zachodzące w Gminie Miejskiej Skierniewice można uznać za reprezentatywne dla wszystkich jednostek tego rodzaju.

W gminie miejskiej Skierniewice występuje szereg klubów sportowych, którym raz w roku przydzielane są środki finansowe w formie dotacji. W tabeli 8 przedstawione zostały informacje dotyczące stowarzyszeń sportowych, związanych z daną dyscypliną sportu, funkcjonujących w Skierniewicach i przysługujących im dotacji w latach 2010-2016.

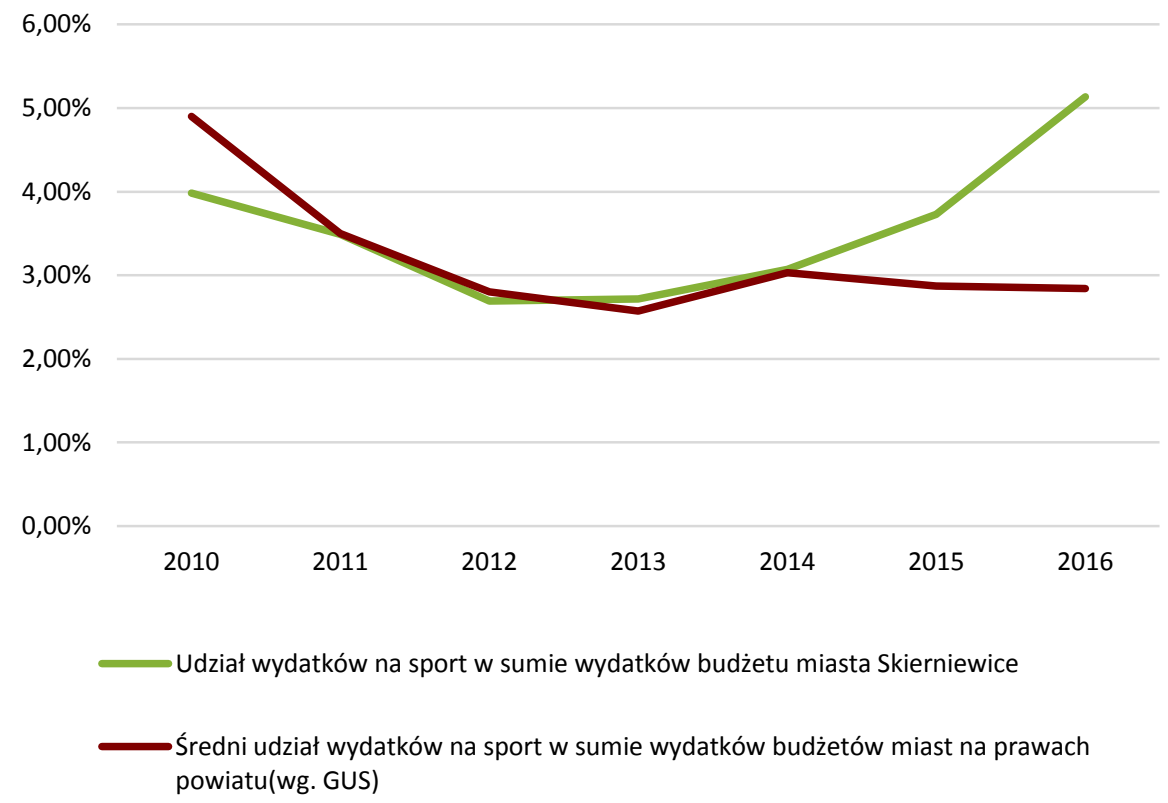

Wykres 4. Zestawienie średniego udziału wydatków na sport w ogólnej liczbie wydatków budżetów miast na prawach powiatu i w Gminie Miejskiej Skierniewice (w tys. zł)

Źródło: opracowanie własne na podstawie Sprawozdań z wykonania budżetu Miasta Skierniewice... [data dostępu 17.03.2018]; Główny Urząd Statystyczny, Gospodarka finansowa jednostek samorządu terytorialnego... [dostęp: 17.06.2019].

W latach 2010-2016 w Skierniewicach dotacje dla stowarzyszeń sportowych nie spadały poniżej poziomu $1,1 \mathrm{mln}$ zł. Ponadto na przestrzeni lat 2010 -2015 nastapił ich wzrost o $196 \mathrm{mln}$ zł. W 2015 roku wartość przyznanych dotacji osiągnęła szczyt na poziomie $1,29 \mathrm{mln}$ zl, by w roku następnym spaść o 41 mln zł. Sportem, który w każdym z badanych okresów był najbardziej dotowany jest piłka nożna. Relatywnie duże dotacje otrzymywały stowarzyszenia 
koszykarskie, pływackie, szachowe, stowarzyszenia ratownictwa wodnego i sportów walki. Na przestrzeni lat 2010-2016 można zauważyć ogólną tendencję wzrostową dotacji, co jest spowodowane m.in. wzrostem poziomu dochodów własnych w tym okresie.

W tabeli 9 przedstawione zostały dochody z działalności sportowej, jakie Skierniewice odnotowały w latach 2010-2016.

Tabela 9. Dotacje dla stowarzyszeń sportowych w latach 2010-2016 w podziale na dyscypliny (w tys. zł)

\begin{tabular}{|l|c|c|c|c|c|c|c|}
\hline Wyszczególnione & 2010 & 2011 & 2012 & 2013 & 2014 & 2015 & 2016 \\
\hline Piłka nożna & 409 & 353 & 303 & 311 & 319 & 395 & 371 \\
\hline Piłka siatkowa & 70 & 74 & 76 & 80 & 65 & 70 & 70 \\
\hline Piłka koszykowa & 110 & 120 & 125 & 110 & 115 & 170 & 114 \\
\hline Hokej na trawie & 20 & 22 & 24 & 28 & 32 & 50 & 50 \\
\hline Lekkoatletyka & 31 & 33 & 33 & 37 & 39 & 49 & 53 \\
\hline Bieganie & 12 & 18 & 20 & 0 & 18 & 28 & 26 \\
\hline Sporty walki & 163 & 188 & 214 & 234 & 245 & 169 & 159 \\
\hline Szachy & 65 & 68 & 70 & 75 & 81 & 88 & 92 \\
\hline Wędkarstwo & 3 & 3 & 3 & 3 & 4 & 8 & 8 \\
\hline Tenis ziemny & 2 & 3 & 0 & 0 & 0 & 8 & 7 \\
\hline Tenis stołowy & 25 & 28 & 31 & 34 & 37 & 35 & 35 \\
\hline Kolarstwo & 12 & 13 & 7 & 0 & 0 & 0 & 0 \\
\hline $\begin{array}{l}\text { Ratownictwo wodne } \\
\text { i pływanie }\end{array}$ & 126 & 163 & 177 & 191 & 207 & 130 & 155 \\
\hline Pozostałe & 52 & 52 & 57 & 80 & 88 & 96 & 115 \\
\hline Razem & $\mathbf{1 1 0 0}$ & $\mathbf{1 1 4 8}$ & $\mathbf{1 1 5 0}$ & $\mathbf{1 1 8 3}$ & $\mathbf{1 2 5 0}$ & $\mathbf{1 2 9 6}$ & $\mathbf{1 2 5 5}$ \\
\hline
\end{tabular}

Źródło: opracowanie własne na podstawie Sprawozdań z wykonania budżetu Miasta Skierniewice... [dostęp: 17.03.2018].

Działalność sportowa jest wysoce niestabilnym źródłem dochodów budżetu Miasta, o czym świadczą gwałtowne zmiany w poszczególnych pozycjach. Władze Skierniewic regularnie pozyskiwały dotacje z Ministerstwa Sportu i Turystyki, z wyjątkiem roku 2012. Ponadto w roku 2010 pozyskano dotacje z samorządu wojewódzkiego. Pozostałą część dochodów w latach 2010-2016 stanowiły kary pieniężne za nieterminową realizację inwestycji z wykorzystaniem dotacji. Dochody z działalności sportowej pokrywały nieznaczną część związanych z nią wydatków, co przedstawione zostało w tab. 10. 
Tabela 10. Wartość dochodów z działalności sportowej gminy miejskiej Skierniewice w latach 2010-2016 (w tys. zl)

\begin{tabular}{|l|c|c|c|c|c|c|c|}
\hline Wyszczególnione & 2010 & 2011 & 2012 & 2013 & 2014 & 2015 & 2016 \\
\hline Kary pieniężne & 304,37 & 7,15 & 0 & 0,77 & 0 & 6,01 & 162,05 \\
\hline Dotacje z województwa & 642,82 & 0 & 0 & 0 & 0 & 0 & 0 \\
\hline $\begin{array}{l}\text { Dotacje z Ministerstwa } \\
\text { Sportu i Turystyki }\end{array}$ & 740,25 & 285 & 0 & 31,3 & 419,4 & 249,8 & 1106,34 \\
\hline Pozostałe & 0 & 0 & 40,05 & 0 & 0 & 9,13 & 8,05 \\
\hline Razem & $\mathbf{1 6 8 7 , 4 3}$ & $\mathbf{2 9 2 , 1 5}$ & $\mathbf{4 0 , 0 5}$ & $\mathbf{3 2 , 0 7}$ & $\mathbf{4 1 9 , 4}$ & $\mathbf{2 6 4 , 9 4}$ & $\mathbf{1 2 7 6 , 4 4}$ \\
\hline
\end{tabular}

Źródło: opracowanie własne na podstawie Sprawozdań z wykonania budżetu Miasta Skierniewice... [dostęp: 17.03.2018].

Tabela 11. Zestawienie dochodów oraz wydatków związanych z działalnością sportową gminy miejskiej Skierniewice w latach 2010-2016 (w tys. zł)

\begin{tabular}{|l|c|c|c|c|c|c|c|}
\hline Wyszczególnione & 2010 & 2011 & 2012 & 2013 & 2014 & 2015 & 2016 \\
\hline Dochody & 1687,43 & 292,15 & 40,05 & 32,07 & 419,4 & 264,84 & 1276,44 \\
\hline Wydatki & 7411,95 & 6746,64 & 4948,42 & 5295,17 & 6512,04 & 8270,02 & 12111,97 \\
\hline Saldo & $-5724,52$ & $-6454,49$ & $-4908,37$ & $-5263,1$ & $-6092,64$ & $-8005,18$ & $-10835,53$ \\
\hline $\begin{array}{l}\text { Pokrycie } \\
\text { wydatków } \\
\text { dochodami }\end{array}$ & $22,77 \%$ & $4,33 \%$ & $0,81 \%$ & $0,61 \%$ & $6,44 \%$ & $3,20 \%$ & $10,54 \%$ \\
\hline
\end{tabular}

Źródło: opracowanie własne na podstawie Sprawozdań z wykonania budżetu Miasta Skierniewice... [dostęp: 18.03.2018].

Wśród mieszkańców Skierniewic została przeprowadzona ankieta drogą internetową. Wśród ankietowanych znalazło się 37 kobiet i 33 mężczyzn, więc udział poszczególnych płci oscylował $\mathrm{w}$ pobliżu $50 \% \mathrm{z}$ nieznaczną przewagą płci żeńskiej. Wśród respondentów największy udział miały osoby w wieku od 19 do 30 lat. Grupa ta liczyła 33 osoby, co stanowiło blisko połowę liczby ankietowanych. Drugą najliczniejszą grupą wiekową byli mieszkańcy Skierniewic, którzy nie przekroczyli 18 roku życia (13 osób). 11 osób miało od 31 do 40 lat (blisko 16\% ankietowanych), natomiast 10 respondentów mieściło się w przedziale od 41 do 60 lat (ponad 14\% ankietowanych). Najmniej liczną, trzyosobową grupę stanowiły osoby, które przekroczyły 60 rok życia.

Wykres 5 przedstawia opinie mieszkańców Skierniewic na temat miejskiej infrastruktury sportowej. 


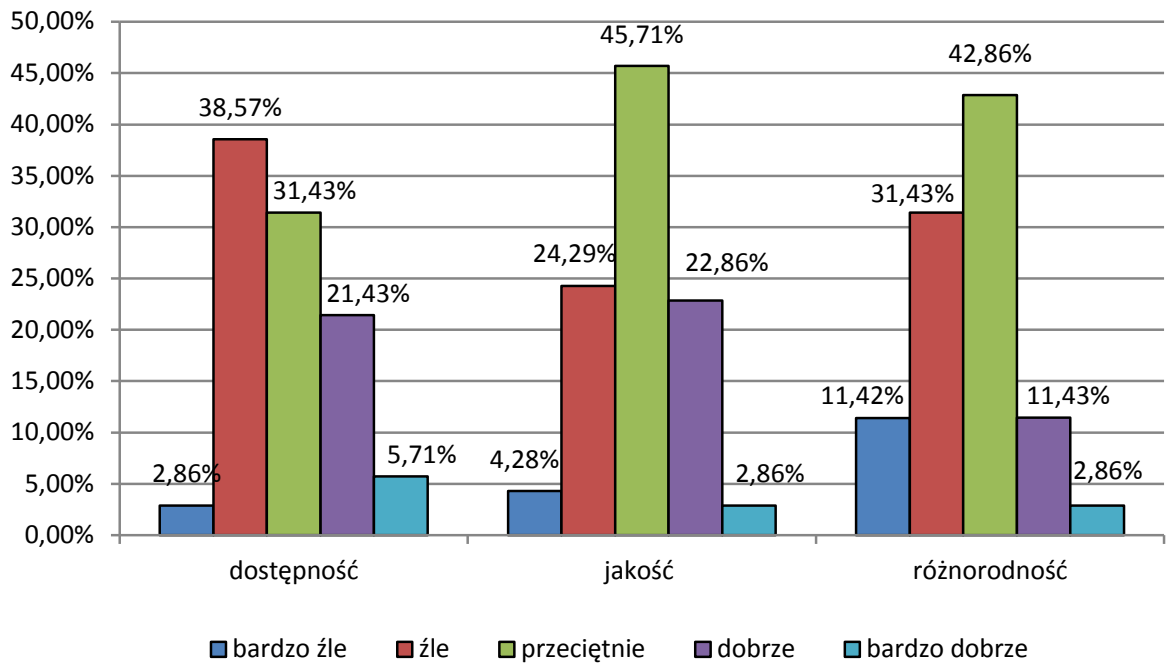

Wykres 5. Miejska infrastruktura sportowa w opinii mieszkańców Skierniewic Google.

Źródło: opracowanie własne na podstawie ankiety przeprowadzonej przy użyciu Formularzy

Opinie Skierniewiczan na temat miejskiej infrastruktury sportowej są podzielone. Blisko 40\% negatywnie oceniło jej dostępność, z czego ok. 3\% uważa, że była ona bardzo zła. Co piąty respondent ocenia ją dobrze, a 4 osoby uważają ją za bardzo dobrą. Co trzecia osoba uważała, że dostępność miejskiej infrastruktury sportowej była przeciętna. W przypadku cech jakościowych oraz różnorodności tej infrastruktury dominowała ocena przeciętna, którą wyraziło ponad 40\% mieszkańców. W przypadku jakości, liczba negatywnych ocen przewyższyła liczbę tych pozytywnych. Sytuacja przedstawia się gorzej w przypadku różnorodności infrastruktury sportowej, którą co trzeci respondent ocenił źle, a aż $11 \%$ osób bardzo źle.

Na wykresie 6 przedstawiona została opinia mieszkańców dotycząca warunków do uprawiania sportu w szkołach, sportu zawodowego i sportu amatorskiego.

Mniej niż 40\% mieszkańców Skierniewic oceniało warunki do uprawiania sportu w szkołach jako przeciętne. Ponadto, opinie złe i bardzo złe przewyższyły opinie pozytywne. Sytuacja kształtuje się podobnie w przypadku warunków do uprawiania sportu amatorskiego, gdzie mniej niż $40 \%$ respondentów oceniało warunki negatywnie. Liczba opinii pozytywnych była najmniejsza w przypadku warunków do uprawiania sportu w celach zarobkowych, gdzie stanowiła $16 \%$ wszystkich opinii. Ponadto $57 \%$ pytanych negatywnie oceniało warunki do uprawiania sportu w tej formie. 


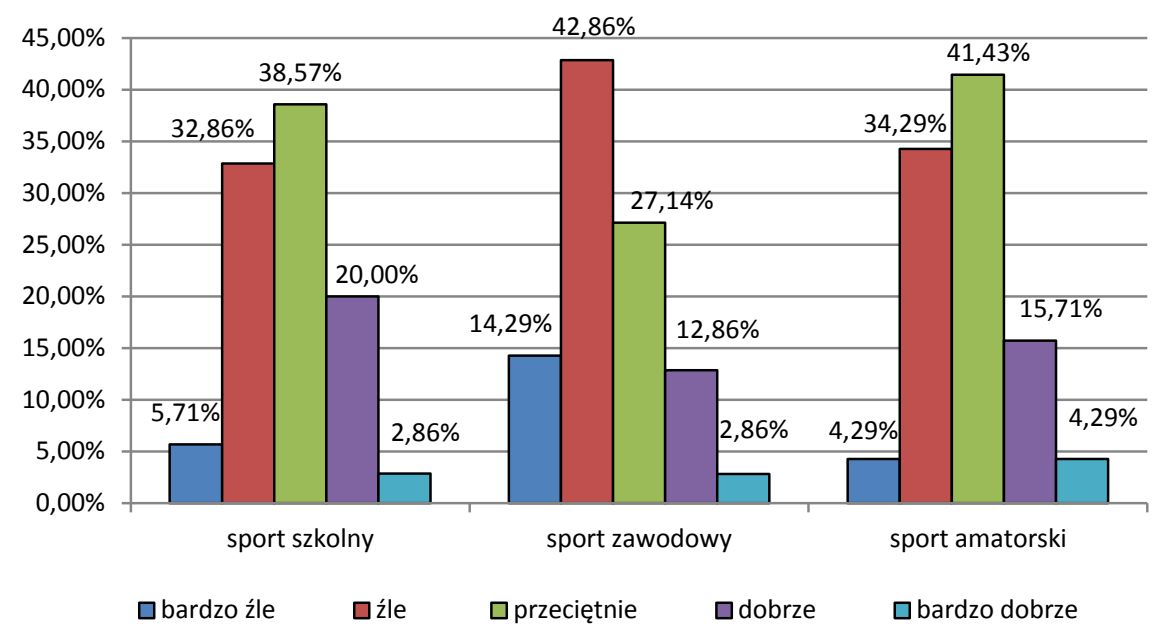

Wykres 6. Warunki do uprawiania sportu w różnych formach w opinii mieszkańców Skierniewic Google.

Źródło: opracowanie własne na podstawie ankiety przeprowadzonej przy użyciu Formularzy

Na wykresie 7 przedstawiona została opinia mieszkańców Skierniewic dotycząca kwoty wydatków Miasta na sport.

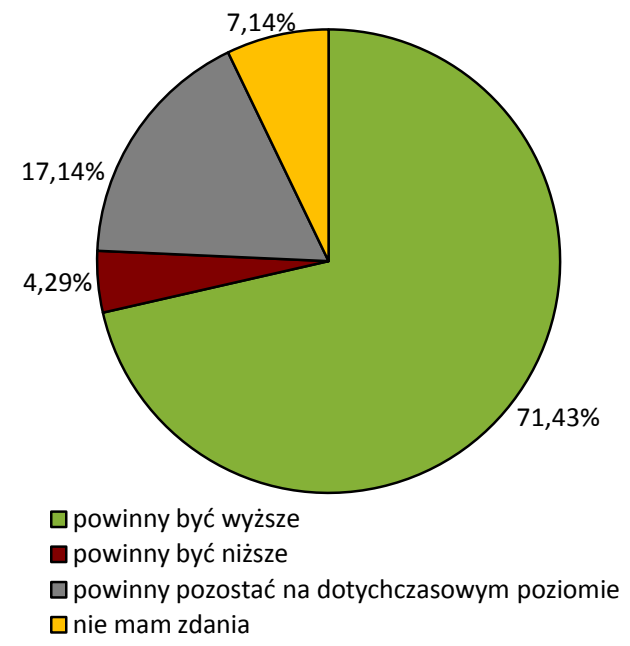

Wykres 7. Opinie mieszkańców na temat kwoty wydatków gminy miejskiej Skierniewice w przyszłości Google.

Źródło: opracowanie własne na podstawie ankiety przeprowadzonej przy użyciu Formularzy 
Wzrost wydatków gminy miejskiej Skierniewice na sport w roku 2016 w stosunku do roku 2010 o ok. 6,2 miliona złotych nie spowodował zadowolenia mieszkańców. Ponad $71 \%$ ankietowanych uważa, że w przyszłości wydatki te powinny jeszcze bardziej wzrosnąć. Około $17 \%$ respondentów twierdzi, że wydatki powinny pozostać na dotychczasowym poziomie, a tylko 3 z 70 osób uważają, że dotychczasowe wydatki były zbyt wysokie i w przyszłości Miasto powinno w mniejszym stopniu wspierać finansowo sport.

\section{PODSUMOWANIE}

Sport i kultura fizyczna stanowią istotny czynnik podnoszący jakość życia i poziom zadowolenia społeczeństw. Są to zjawiska powszechne, występujące na całym świecie, których istnienie jest niezbędne dla egzystencji wielu ludzi. $\mathrm{Z}$ tego powodu kluczowe jest zwiększanie dostępności, poprawianie jakości, a także dbanie o różnorodność sportowej infrastruktury. Ważną rolę w tym procesie odgrywa samorząd gminny. Poprawne wywiązywanie się gmin z wykonywania zadań własnych, jakimi są sport i kultura fizyczna wydatnie zwiększa poziom aktywności fizycznej obywateli, a wraz z nim poprawia się ich stan zdrowia. Sport jest też doskonałym narzędziem promocji gminy. Gwarantem efektywnej realizacji zadań z zakresu kultury fizycznej i sportu jest systematyczne badanie potrzeb mieszkańców, a następnie inteligentne kształtowanie struktury wydatków na budowę, utrzymanie i modernizację obiektów sportowych, dotacje dla klubów, nagrody i stypendia dla najlepszych sportowców, czy organizację imprez i wspieranie lokalnych inicjatyw.

W artykule postawiono tezę mówiącą, że poziom dochodów własnych gminy determinuje zakres realizowanych zadań w obszarze sportu i kultury fizycznej. Gmina Miejska Skierniewice została uznana za jednostkę, która może stanowić przedmiot badania reprezentatywny dla innych jednostek o podobnej formie organizacyjnej jaką jest miasto na prawach powiatu. Fakt ten został potwierdzony poprzez analizę udziału wydatków na sport i kulturę fizyczną w Skierniewicach w latach 2010-2016 i porównanie uzyskanych wartości $\mathrm{z}$ ogólnymi danymi dotyczącymi miast na prawach powiatu $\mathrm{w}$ tych samych latach, a do przeprowadzenia analizy została wykorzystana średnia arytmetyczna oraz wskaźnik korelacji. Badanie struktury dochodów i wydatków przeprowadzone w Gminie Miejskiej Skierniewice wykazało, że wzrost dochodów własnych jednostek samorządu terytorialnego powoduje, że wzrasta liczba środków, które gmina przekazuje na cele związane z kulturą fizyczną. Ponadto samorządy mogą pozyskiwać środki pozyskane w formie dotacji i dysponują szerokim zasobem bezpośrednich czy pośrednich sposobów wspomagania działalności sportowej i związanych z nią instytucji. Istotny jest wybór odpowiednich kierunków 
i dróg inwestycji, który zapewnia jak największy stopień zadowolenia ludności. Zwiększenie wydatków na działalność sportową nie zapewni przychylności społeczeństwa, jeśli środki będą wydatkowane w sposób nieprzemyślany.

\section{BIBLIOGRAFIA}

Babczuk A. (red.), 2012, Finansowanie sportu przez samorzad terytorialny, C.H.Beck, Warszawa.

Babczuk A., Talik A. (red.), 2014, Finansowanie sportu ze środków publicznych, C.H.Beck, Warszawa.

Bończak-Kucharczyk E., 2013, Ustawa o gospodarce nieruchomościami. Komentarz, Wolters Kluwer, Warszawa.

Dylewski M., Filipiak B., Gorzałczyńska-Koczkodaj M., 2006, Finanse samorządowe. Narzędzia, decyzje, procesy, Wydawnictwo Naukowe PWN, Warszawa.

Główny Urząd Statystyczny, Gospodarka finansowa jednostek samorządu terytorialnego z lat 2010-2016, https://stat.gov.pl/obszary-tematyczne/rachunki-narodowe/statystyka-sektorainstytucji-rzadowych-i-samorzadowych/

Informacje z wykonania budżetu Miasta Skierniewice z lat 2010-2016 [dostęp: 14.03 .2018 r.].

Konstytucja Rzeczypospolitej Polskiej z dn. 2 kwietnia 1997 r., Dz.U. nr 78, poz. 483 z późn. zm.,

Leciak M. (red.), 2017, Leksykon prawa sportowego. 100 podstawowych pojęć, C.H. Beck, Warszawa 2017.

Niedzielski P., Witek J. (red.), 2011, Sport i rekreacja a wyzwania wspótczesnej cywilizacji, Wydawnictwo Naukowe Uniwersytetu Szczecińskiego, Szczecin.

Pietrzak B., Polański Z., Woźniak B. (red.), 2008, System finansowy w Polsce, Wydawnictwo Naukowe PWN, Warszawa.

Podstawka M. (red.), 2013, Finanse. Instytucje, instrumenty, podmioty, rynki, regulacje, Wydawnictwo Naukowe PWN, Warszawa.

Prawo budżetowe państwa i samorząu.

Rzeszowski J., 217, Finansowanie klubów sportowych z budżetu jednostek samorzadu terytorialnego - sposoby wsparcia i studium interpretacji przepisów, „Prawo Budżetowe Państwa i Samorządu", nr 2.

Sawicka Krystyna, 2012, Finansowanie rozwoju sportu z budżetu jednostki samorzadu terytorialnego [w:] Prawne aspekty prywatyzacji [praca zbiorowa], Prawnicza i Ekonomiczna Biblioteka Cyfrowa, Uniwersytet Wrocławski, Wydział Prawa Administracji i Ekonomii, Wrocław.

Skierniewice - podstawowe informacje, http://www.polskawliczbach.pl/Skierniewice.

Sporek T., 2007, Sponsoring sportu w warunkach globalizacji, DIFIN, Warszawa.

Sprawozdania z wykonania budżetu Miasta Skierniewice w latach 2010-2016 www.bip.um.skierniewice.pl.

Sznajder A., 2008, Marketing sportu, PWE, Warszawa.

Toczek-Werner S., 2005, Podstawy rekreacji i turystyki, AWF Wrocław, Wrocław.

Ustawa z dnia 13 listopada 2003 r. o dochodach jednostek samorządu terytorialnego, Dz.U. 2003, nr 203, poz. 1966.

Ustawa z dnia 24 kwietnia 2003 r. o działalności pożytku publicznego i o wolontariacie, Dz.U. 2003, nr 96, poz. 873, ze zm.

Ustawa z dnia 25 czerwca 2010 r. o sporcie, Dz.U. 2010, nr 127, poz. 857, ze zm.

Ustawa z dnia 27 sierpnia 2009 r. o finansach publicznych, Dz.U. 2009, nr 157, poz. 1240, ze zm.

Ustawa z dnia 8 marca 1990 r. o samorządzie gminnym, Dz.U. 1998, nr 162, poz. 1126.

Witkowski B. (red.), 2018, Statystyka w zarzadzaniu, Wydawnictwo Naukowe PWN, Warszawa. 


\title{
SPORTS FINANCING BY LOCAL GOVERNMENT UNITS IN POLAND - CASE STUDY
}

\begin{abstract}
The article contains information on the concept of sport and physical culture and their financing by local government units. Nowadays sport is ubiquitous. For some people it is a way to spend free time, relax, take care of health, while for others it is a source of earnings. Providing the right conditions for its cultivation is an important aspect of the activities of central and local authorities. Providing adequate sports infrastructure is key to ensure its development and ensure appropriate legal and financial conditions at the lowest levels of the structure of public authorities. Local government units face the problem of obtaining funds to finance sport and their appropriate distribution. The purpose of the article is to present the budget expenditure of the Skierniewice Commune for sport and physical culture, as well as the evaluation of the method of distribution of funds by local government units.
\end{abstract}

Keywords: Local government unit, financing, sport, public finances. 